\title{
Hubungan Antara Kuantitas dan Kualitas Tidur Dengan Uji Kompetensi DIII Keperawatan Poltekkes Kemenkes Jakarta I
}

\author{
Amelia Arnis \\ Dosen Jurusan Keperawatan Poltekkes Kemenkes Jakarta I \\ Email: arnisamelia@gmail.com
}

\begin{abstract}
Abstrak
Kualitas tidur seseorang dikatakan baik apabila tidak menunjukkan berbagai tanda kekurangan tidur dan tidak mengalami masalah dalam tidurnya. Gangguan tidur banyak ditemui di kalangan dewasa muda terutama mahasiswa yang nantinya dapat menyebabkan berkurangnya konsentrasi belajar dan gangguan kesehatan. Hal ini dapat menyebakan tidak tercapainya prestasi akademik secara optimal karena proses belajar menjadi terganggu. Tujuan penelitian ini adalah untuk menentukan hubungan kuantitas dan kualitas tidur dengan Uji kompetesi DIII Keperawatan Poltekkes Kemenkes Jakarta I. Desain penelitian yang digunakan adalah metode analitik dengan rancangan cross sectional. Sampel penelitian adalah total sampling mahasiswa DIII keperawatan Poltekkes Kemenkes Jakarta I yang telah di wisuda tahun 2017 dengan jumlah 76 responden. Data kualitas tidur diambil dengan menggunakan indeks kualitas tidur Pittsburg (PSQI) dan nilai kelulusan uji kompetensi 2017. Hasil penelitian ini menunjukkan tidak ada hubungan antara kualitas dan kuantitas tidur dengan kelulusan uji kompetensi keperawatan.
\end{abstract}

Kata Kunci : Uji kompetensi, Kualitas dan kuantitas tidur

\footnotetext{
Abstract

A person's sleep quality is said to be good if it does not show a variety of signs of sleep deprivation and does not experience sleep problems. Sleep disorders are commonly found among young adults, especially students who later can lead to reduced concentration of learning and health problems. This can cause the achievement of academic achievement optimally because the learning process is disrupted. The purpose of this study was to determine the relationship of quantity and quality of sleep with the competency test DIII Nursing Ministry of Health Polytechnic Jakarta I. The research design used was an analytical method with a cross sectional design. The research sample was a total sampling of students DIII Health Ministry Polytechnic nursing Jakarta I who had graduated in 2017 with 76 respondents. Sleep quality data was taken using the Pittsburg sleep quality index (PSQI) and the 2017 competency test graduation value. The results of this study indicate there is no relationship between the quality
}

and quantity of sleep and the graduation of nursing competency tests.

Keywords: Test of competence, quality and quantity of sleep

\section{Pendahuluan}

Kualitas tidur adalah kepuasan seseorang terhadap tidur, shingga seseorang tersebut tidak memperlihatkan perasaan lelah, mudah terangsang dan gelisah, lesu dan apatis, kehitaman disekitar mata, kelopak mata bengkak, konjungtiva merah, mata perih, perhatian terpecah - pecah, sakit kepala dan sering menguap atau mengantuk (Hidayat, 2006). Kualitas tidur, menurut American Psychiatric Association (2009) dalam Wavy (2008) didefinisikan sebagai suatu fenomena kompleks yang melibatkan beberapa dimensi.

Kualitas tidur meliputi aspek kuantitatif dan kualitatif tidur, seperti lamanya tidur, waktu yang diperlukan untuk bisa tertidur, frekuensi terbangun dan aspek subjektif seperti kedalaman dan kepulasan tidur (Daniel et al, 1998; Buysee, 1998). Persepsi mengenai kualitas tidur itu sangat bervariasi dan individual yang dapat dipengaruhi oleh waktu yang digunakan untuk tidur pada malam hari atau efisiensi tidur. Beberapa penelitian melaporkan bahwa efisiensi tidur pada usia dewasa muda adalah 80-90\% (Dament et al, 1985; Hayashi \& Endo, 1982 dikutip dari Carpenito, 1998). Di sisi lain, Lai (2001) dalam Wavy (2008) menyebutkan bahwa kualitas tidur ditentukan oleh bagaimana seseorang mempersiapkan pola tidurnya pada malam hari seperti kedalaman tidur, kemampuan tinggal tidur, dan kemudahan untuk tertidur tanpa bantuan medis. Kualitas tidur yang baik dapat memberikan perasaan tenang di pagi hari, perasaan energik, dan tidak mengeluh gangguan tidur. Dengan kata lain, memiliki kualitas tidur baik sangat penting dan vital untuk hidup sehat semua orang.

Uji kompetensi adalah suatu proses untuk mengukur pengetahuan, ketrampilan, dan sikap tenaga kesehatan sesuai standar profesi, khususnya yang kita bahas kali ini adalah perawat. Untuk menjamin setiap perawat memiliki kompetensi yang dipersyaratkan sebelum melaksanakan praktik pelayanan keperawatan, pemerintah telah mengeluarkan Peraturan Menteri Kesehatan No. 1796 tentang Registrasi Tenaga Kesehatan. 
Sebelum tenaga kesehatan di registrasi tenaga kesehatan wajib mengikuti uji kompetensi. Pada uji kompetensi ini ada tiga aspek yang perlu diperhatikan dalam mengukur tenaga kesehatan perawat yaitu pengetahuan, keterampilan, dan sikap. Materi uji kompetensi disusun mengacu kepada standar kompetensi yang tercantum dalam standar profesi. Materi uji kompetensi dikembangkan dan disusun oleh divisi standarisasi MTKI berkoordinasi dengan Dirjen DIKTI Kementerian Pendidikan Nasional dan LPUK serta Tim Ad-hock di MTKI yang berasal dari masing-masing organisasi profesi (Kemenkes RI, 2010: 16).

Uji kompetensi perawat dilaksanakan secara nasional sejak tahun 2013 dengan waktu ujian selama 180 menit dengan soal yang harus dikerjakan sebanyak 180 soal. Untuk dapat lulus uji kompetensi diperlukan persiapan yang baik dalam menghadapi ujian seperti konsentrasi, berlatih mengerjakan soal - soal ukom, fisik, serta motivasi. Menurut Khasanah, dkk (2017) motivasi dan karakteristik kepribadian adalah salah satu faktor yang mempengaruhi kelulusan uji kompetensi perawat. Selain itu Try out, prestasi akademik, serta gaya belajar juga mempengaruhi kelulusan uji kompetensi perawat (Abdillah, 2016).

\section{Metode}

Desain penelitian yang digunakan dalam penelitian ini adalah analitik dengan rancangan cross sectional. Dalam penelitian ini pengumpulan data didapatkan dari responden dengan menggunakan kuesioner serta melihat hasil kelulusan uji kompetensi perawat.

Respomdem yang diambil berjumlah 76 lulusan Poltekkes Jakarta I yang telah mengkuti uji kompetensi pada tahun 2017 dan bersedia menjadi responden. Pengambilan data dilakukan di poltekkes kemenkes Jakarta I jurusan keperawatan yang dilakukan pada bulan Oktober 2017.

Teknik Analisa data yang digunakan oleh peneliti adalah Analisa univariat dan bivariat dengan menggunakan program software statistic.

\section{Hasil}

Hasil penelitian menunjukkan bahwa kualitas tidur mayoritas responden $62(81,6 \%)$ orang tidur selama $>7$ jam pada malam hari dan hanya 2 orang $(2,6 \%)$ yang tidur selama $5-6$ jam pada malam hari.

Gambaran nilai uji kompetensi responden pada bulan Oktober 2017 menunjukkan bahwa lulusan perawat poltekkes kemenkes Jakarta I yang mendapatkan nilai 71 dan 76 masing - masing sebanyak $10(13,2 \%)$ orang, nilai 70 sebanyak 8 $(10,5 \%)$ orang dan nilai 78 sebanyak $7(9,2 \%)$ orang. Nilai tertinggi yang di peroleh oleh lulusan mahasiswa sebesar 81 sebanyak $2(2,6 \%)$ orang dan nilai terendah 60 sebanyak $1(1,3 \%)$ orang. Nilai batas lulus untuk uji kompetensi yang di tetapkan oleh Panitia Nasional Uji Kompetensi (PNUK) pada bulan Oktober 2017 adalah 45,04. Sehingga seluruh responden berada di atas nilai batas lulus dan dinyatakan kompeten.

Untuk mengidentifikasikan hubungan kualitas tidur dengan kelulusan uji kompetensi digunakan uji statistik T-test.

Tabel 1.1

Distribusi Hubungan antara kualitas tidur dengan Nilai Ukom

\begin{tabular}{|l|l|l|l|l|l|}
\hline Variabel & Mean & SD & SE & N & $\begin{array}{l}\text { P } \\
\text { value }\end{array}$ \\
\hline $\begin{array}{l}\text { Kualitas } \\
\text { tidur baik }\end{array}$ & 73,87 & 3,852 & 0,995 & 15 & 0,545 \\
\hline $\begin{array}{l}\text { Kualitas } \\
\text { tidur } \\
\text { buruk }\end{array}$ & 72,57 & 4,268 & 0,546 & 61 & \\
\hline
\end{tabular}

Berdasarkan tabel 1.1 rata - rata nilai ukom responden yang memiliki kualitas tidur yang baik adalah 73,87 , rata - rata niliai responden dengan kualitas tidur yang buruk adalah 72,57. Hasil uji statistik bahwa $\mathrm{P}$ value untuk kualitas tidur yang diperoleh adalah 0,545 . Hal ini menunjukkan bahwa $\mathrm{P}$ value $>\alpha$ sehingga $\mathrm{H} 0$ ditolak. Maka dapat disimpulkan bahwa tidak ada hubungan antara kualitas tidur dengan nilai uji kompetensi

Sedangkan untuk hubungan antara kuantitas tidur dengan uji kompetensi menggunakan uji statistik Anova dikarenakan data yang ada termasuk dalam katagorik lebih dari 2 kelompok.

Tabel 1.2

Distribusi Hubungan antara Kuantitas tidur dengan Nilai ukom

\begin{tabular}{|c|c|c|c|c|}
\hline \multicolumn{5}{|c|}{ THal uरणII } \\
\hline Variabel & Mean & SD & $95 \% \mathrm{CI}$ & $\begin{array}{c}P \\
\text { value }\end{array}$ \\
\hline $\begin{array}{l}\text { Lebih dari } \\
7 \text { jam }\end{array}$ & 73,26 & 4,004 & $\begin{array}{l}72,24- \\
74,27\end{array}$ & 0,082 \\
\hline $6-7$ jam & 70,92 & 5,054 & $\begin{array}{l}67,71- \\
74,13\end{array}$ & \\
\hline 5-6 jam & 71 & 0 & $\begin{array}{l}71,00- \\
71,00\end{array}$ & \\
\hline
\end{tabular}

Berdasarkan tabel 1.2 rata - rata waktu responden tidur lebih dari 7 jam adalah 73,26 dengan standar deviasi 4,004. Untuk responden yang rata - rata kuantitas tidurnya $6-7$ jam adalah 70,92 dengan standar deviasi 5,054. Pada responden yang rata rata kuantitas tidurnya 5-6 jam adalah 71 dengan standar deviasi 0 . Hasil uji statistik didapatkan nilai $\mathrm{p}=0,082$, berarti pada alpha $5 \%$ terlihat tidak ada hubungan antara kuantitas dengan nilai kelulusan uji kompetensi.

\section{Pembahasan}

Hasil penelitian ini menunjukkan bahwa 61 orang $(80,3 \%)$ mempunyai kualitas tidur yang buruk, dan 15 orang $(19,7 \%)$ memiliki kualitas tidur yang baik. Hal ini sejalan dengan penelitian 
Sarfriyanda, dkk (2015) yang menggambarkan 162 $(82,2 \%)$ orang mahasiswa keperawatan mengalami kualitas tidur yang buruk dan $35(17,8 \%)$ mahasiswa memiliki kualitas tidur yang baik. Hal ini dapat disebabkan karena mahasiswa kesehatan memiliki jadwal kuliah yang cukup padat serta tugas yang banyak sehingga mahasiswa beresiko mengalami gangguan tidur. Selain itu faktor aktifitas sosial dan faktor elektronik seperti akses internet atau gadget juga dapat mempengaruhi kualitas tidur seseorang. Stress, depresi, ansietas, penyakit, lingkungan, alkohol, makanan dan minuman juga dapat mempengaruhi kualitas tidur seseorang (Potter \& Perry, 2005). Oleh karena itu penelitian lebih lanjut untuk memastikan faktor - faktor yang yang mempengaruhi kualitas tidur dan kuantitas tidur di kalangan mahasiswa poltekkes kemenkes jakarta 1.

Pada penelitian ini didapatkan bahwa tidak ada hubungan antara kualitas tidur dengan kelulusan uji kompetensi setelah dilakukan analisa bivariat menggunakan uji T-test. Didapatkan nilai p>0,005. Hal ini senada dengan penelitian Syafriyanda, dkk (2015) yang didapatkan $82,2 \%$ responden memiliki kualitas tidur dan kuantitas tidur yang buruk tetapi memiliki prestasi belajar yang baik. Marpaung (2013) juga mendapatkan hasil yang sama, yaitu tidak ada hubungan antara kualitas dan kuantitas tidur yang buruk terhadap prestasi belajar yang baik.

Penelitian yang dilakukan Rasyid (2011) pada mahasiswa kedokteran juga menunjukkan hasil yang sama yaitu tidak terdapat hubungan yang bermakna antara kuantitas tidur dan daya ingat $(\mathrm{p}=0,926)$ serta tidak terdapat hubungan yang bermakna antara kuantitas tidur dengan tingkat konsentrasi $(\mathrm{p}=0,084)$. Genzel (2013) juga menemukan hasil yang sama pada penelitiannya yang mendapatkan bahwa kualitas tidur tidak mempunyai hubungan yang bermakna dengan nilai ujian.

Meskipun hal ini berbeda dengan penelitian Fenny dan supriatmo (2016) yang mendapatkan adanya hubungan antara kualitas dan kuantitas tidur dengan presentasi belajar pada mahasiswa FK USU $(\mathrm{p}<0,0001)$.

Penelitian ini memiliki implikasi terhadap dunia pendidikan keperawatan khususnya di Poltekkes Kemenkes Jakarta I. Hasil penelitian ini dapat dijadikan dasar mengenai pentingnya tidur yang berkualitas pada lulusan mahasiswa berkaitan dengan uji kompetensi.

Implikasi penelitan ini dapat menambah informasi untuk pengembangan keperawatan terutama berkaitan dengan pemenuhan kebutuhan dasar mahasiswa akan tidur. Hasil tersebut dapat dijadikan data dasar dalam mengengmbangkan penelitian keperawatan selanjutnya. Oleh karena itu, untuk penelitian lebih lanjut sebaiknya dilakukan penelitian mengenai faktor - faktor lain yang mempengaruhi kualitas tidur mahasiswa.
Dalam bidang pendidikan keperawatan, pemenuhan kebutuhan dasar yaitu tidur merupakan hal yang penting. Hasil penelitian ini memberikan suatu gambaran bahwa sebagian besar mahasiswa keperawatan Poltekkes Kemenkes Jakarta I memiliki kualitas tidur yang buruk. Hasil ini dapat menjadi dasar informasi bagi pendidik di Poltekkes Kemenkes Jakaera I untuk dapat dilakukan pertimbangan dalam penyusunan rancangan akademik yang lebih efektif sehingga mahasiswa memiliki waktu tidur yang lebih baik.

\section{Kesimpulan}

Penelitian ini bersifat kuantitatif dengan menggunakan desain cross sectional analitik untuk mengetahui hubungan antara kualitas dan kuantitas tidur dengan kelulusan uji kompetensi perawat. Responden dalam penelitian ini diambil secara total sampling sebanyak 76 orang. Pengambilan data dilakukan di Poltekkes Kemenkes Jakarta I dengan menggunakan kuesioner yang terdiri dari pertanyaan demografi dan pertanyaan dari Pittsburgh Sleep Quality Index (PSQI) terkait dengan kualitas dan kuantitas tidur. Untuk nilai kelulusan uji kompetensi didapatkan data dari Panitia Nasional Uji Kompetensi. Hasil dari penelitian ini antara lain :

1. Mayoritas responden $(81,6 \%)$ menunjukkan durasi tidur selama lebih dari 7 jam pada malam hari.

2. Kualitas tidur responden sebanyak $80,3 \%$ memiliki kualitas tidur yang buruk selama satu bulan terakhir.

3. Seluruh responden berkompeten dan dinyatakan lulus uji kompetensi yang dilihat dari nilai uji kompetensi diatas nilai batas lulus uji kompetensi pada bulan oktober 2017 sebesar 45,04.

4. Hasil uji hipotesis dengan analisis T-test memberikan kesimpulan bahwa tidak ada hubungan antara Kualitas tidur dengan nilai kelulusan uji kompetensi. Hal ini terlihat pada sebagian besar responden memiliki kualitas tidur yang buruk tetapi semua responden lulus uji kompetensi.

5. Kuantitas tidur juga tidak berhubungan dengan kelulusan uji kompetensi DIII perawat berdasarkan hasil uji hipotesis dengan Annova. Mayoritas responden $(81,8 \%)$ memiliki kuantitas tidur lebih dari 7 jam.

\section{Daftar Pustaka}

Abdillah, A. Analisis Faktor - faktor yang mempengaruhi kelulusan Uji Kompetensi Ners Indonesia. Jurnal Penelitian Administrasi Publik. 2016. Vol 2 (2) : $373-380$.

Bussye DJ. Reynold CF, Monk TH, Berman SR, Kuffer DJ. The Pittsburgh sleep quality index : a new instrument for psychiatric and research (diunduh 23 desember 2016) tersedia dari 
http://sakai.ohsu.ed/acces/content/brodym/N547A \%20spring08/apendix/PSQI.doc

Contreras, F. H., Lopez, E. M., Roman, P. A. L., Garrido, F., Santos, M. A., \& Amat, A. M. 2014. Reliability and validity of the spanish version of the Pittsburgh Sleep Quality Index (PSQI) in patients with fibromyalgia. Rheumatol Int. 34: 929-936. 2014

Cooper, D.R. dan Schindler, P.S. Business Research Methods. New York : McGraw-Hill.

Fenny \& Supriatmo. Hubungan kualitas dan kuantitas tidur dengan prestasi belajar pada mahasiswa fakultas kedokteran. Jurnal Pendidikan Kedokteran Indonesia. 2016. Vol 5 (3) : $140-147$

Genzel, L., et al.. Sleep timing is more important than sleep lenght or quality for medical school performance. Chronobiology International, 1-6. .2013

Guyton A. C., Hall J. E. Buku Ajar Fisiologi Kedokteran. Edisi 9. Jakarta : EGC. 1997.

Hair, J.F. Jr., Black, W. C., Babin, B.J., \& Anderson, R.E. 2016. Multivariate Data Analysis. New Jersey: Pearson Prentice Hall. 2016.

Hidayat, AA. Kebutuhan dasar manusia. Jakarta : Salemba Medika. 2009

Indrawati, N. Perbandungan kualitas tidur mahasiswa yang mengikuti UKM dan tidak mengikuti UKM pada mahasiswa reguler FIK UI. Skripsi. 2012.

Johanna, Christa \& Jachens. Sleep Disturbances \& Healthy Sleep. The Association of Waldorf Schools of North America. 2004.

Khasanah, U., Sudiyanto, H., Wahyu, F., \& Fatmawati, A. . Analisis faktor-faktor yang berhubungan dengan tingkat kelulusan Uji kompetensi mahasiswa S1 Keperawatan di STIKES Majapahit Mojokerto. Medica Majapahit. 2017. Vol 9 (2) : 182 - 192

Lanywati, E. Insomnia : gangguan sulit tidur. Jakarta : EGC. 2001.

Marpaung, P. P. Gambaran lama tidur dengan prestasi belajar siswa. Scholarly article, 2013. 545-549.

Masfuri. Uji Kompetensi Perawat Indonesia. Journal Persatuan Perawat Nasional Indonesia. 2016. Volume 1: 1

Potter, P. A., \& Perry, A. G. Fundamental keperawatan. Jakarta: Salemba Medika. 2005.

Rasyid. The relationship of quantity of sleep, concentration and short term memory capability in the students of Brawijaya University. Scholarly article. 2011.

Sobur, A. Psikologi umum. Bandung : Pustaka setia. 2006.
Susanto H. Meningkatkan konsentrasi siswa melalui optimalisasi modalitas belajar siswa (diunduh 23 desember 2016). Tersedia dari: http://www.bpkpenabur.or.id

Wavy, W. W. Y. The Relationship between Time Management, Perceived Stress, Sleep Quality and Academic Performance among University Students. Tesis (tidak diterbitkan). Hong Kong Baptist University. 2008. 